\title{
English Teachers' Perception on Using Google Classroom
}

\author{
Rini Septa Angraini $\mathrm{S}^{1,{ }^{*}}$ Jufrizal $^{1} \mathrm{Zul}_{\text {Amri }}{ }^{1}$ \\ ${ }^{1}$ English Education, Universitas Negeri Padang, Padang, Indonesia \\ *Corresponding author. Email: riniseptaangraini.s@gmail.com
}

\begin{abstract}
Online learning has become an alternative for schools and any other education programs, since the unexpected situation due to the pandemic. Various online tools are provided for this virtual learning. One of the most popular tools used by the teachers is Google Classroom. This research was aimed to determine teachers' perception on using Google Classroom as online learning platform at Pondok Pesantren Sumatera Thawalib Parabek. The type of this research was descriptive quantitative. The data were teacher's responses on the interview questions, checklist, and questionnaire. These data were collected from 5 teachers of second grade students at Pondok Pesantren Sumatera Thawalib Parabek. The data were analyzed using descriptive analysis. The finding shows that $71 \%$ of teachers' perceptions are categorized as positive percentage. This finding indicated that teachers' have positive perception on using Google Classroom at Pondok Pesantren Sumatera Thawalib.
\end{abstract}

Keywords: Teachers' Perception, Google Classroom, Online Learning

\section{INTRODUCTION}

In today's situation, online learning is essential since the social distancing should be applied to control the pandemic. Online learning is considered as an effective solution for today's condition. Online learning is a process where learning activity; students-teachers interaction and material distribution are conducted through internet. Anderson (2008) briefly defines online learning as a set of learning process where its process is conducted in distance, thus it is more flexible in time and place for both teacher and student [1]. This idea impresses on the flexibility of the learning process. It is valid that one of the reasons of the online learning process is as an alternative for classroom learning process that need a specific time and place.

According to Carliner, online learning means educational material which presented on a computer[2]. Online learning is learning or education through the internet, networks and indenpendent computer[3]. According to this idea, online learning is a learning type that conducted through a computer. This idea defines online learning as a specific teaching and learning activity conducted through a computer only. In today's era, this online learning in not only can be held through computer but also through smartphone and other types of gadget. Online learning involves the presentation and deliver the material using web, the learner and the learning process become the focus of online learning[4].This expert directly explains that the use of the online learning is to deliver the material to the students that cannot meet the teacher in the classroom. However, this definition is actually referred to a teaching and learning activity that is not conducted in the classroom, but through computer that linked to the internet. Therefore, this definition is actually gives a simple and clear definition on the online learning.

Specifically, Dhull and Sakshi (2017) States that Online Learning includes variety of technologies such as email, web, chat, audio and video conferences that delivered through internet to help the education process[5]. This statement implies that the online learning is a flexible learning activity where the teachers have many options in implementing this program. In fact, online learning has been implemented by the teachers through various digital or virtual applications. Google Classroom is one of the mostly used applications in online learning.

According to Beal, Google Classroom platform facilitates teacher and students interaction; by using this tool, teacher may freely create and share tasks for the students in Google Classroom platform[6]. It also enables the teachers to build learning groups for sharing assignments and announcements in this platform. Google Classroom platform can make students active participants. This idea explains Google Classroom as an online learning platform that facilitates teacher and students in sharing assignments and announcements. Sharing assignments and announcements is an essential 
activity in learning process. Thus, Google Classroom provides what the teacher and student need in learning process.

Janzen (2014), explains that Google Classroom is designed to simplify learning interaction and instruction with several functions; assign a task, and communicating with the individual in the class through announcements, email, and notifications [7].

Furthermore, Iftakhar (2016) states that Google Classroom integrates other Google applications such as Google Docs, Google Slides and Google Drive. Nonetheless, the process of providing tasks, evaluation and the feedback is streamlined[8]. This idea emphasizes on the rich features of Google Classroom. This advantage is precise. One of the main advantage provided by Google Classroom that cannot be found in classroom learning is its' features.

Nagele said that teachers can use Google Classroom to create student-centric, collaborative, and memorable active courses in that provides easy to use learning features that all students can collaborate[9]. Obviously, Google Classroom provides useful online learning for teachers and students. Google Classroom helps all categories of students, including adult students. The use of the Google Classroom platform makes the learning process easier and more meaningful[10]. Hence, the use of Google Classroom make it easier for teacher to manage learning process and submit information properly and accurately to students. It also has some advantages, such as being paperless, while there is an internet connection and any device, it can be accessed anytime and anywhere, communicating between teachers and students. Therefore, Google Classroom makes it easier for teacher to deal with students' homework. However, this idea is not always appropriate.

Despite its benefits, Google Classroom has some limitations. Pappas highlights the restricted integration option in Google Classroom, it is not synchronized with calendar, the feature and notification is not updated automatically in Google Classroom, and students can't share document with others without permision from the teacher[11]. These limitations are actually understood for that is always happening for any technology feature. Thus, the teacher creativity is always needed to manage every types of learning process. Google Classroom is an online learning tool that effectively simplifies learning process. However, there are also several limitations that should be managed creatively by the teachers.

Online learning has been conducted regularly in recent year. Google Classroom as one of the tools for this online learning is also widely used, especially at Pondok Pesantren Sumatera Thawalib Parabek. In spite of benefit and limitation of it's used, Google Classroom is very different from normal classroom learning.

The teachers and students face significant changes in learning process. Teachers and students no longer have a direct and face-to-face interaction. Even the use of Google Classroom is clearly described, but some teachers and students are struggle in this online process. Although this type of online learning is considered as effective by several study, but the teacher real perception on using Google Classroom is needed to investigate. Thus, this research is conducted to find out how the teachers use Google Classroom platform in teaching English and to find out the teachers' perception on using of Google Classroom at Pondok Pesantren Sumatera Thawalib Parabek.

\section{METHOD}

The type of this research is descriptive quantitative. This research was conducted to five teachers at second grade as sample that have been chosen randomly and purposefully. The data were collected through checklist, interview, and questionnaire. The researcher then described, calculated, analyzed, and classified all the data collected. The teacher perception on the Google Classroom were identified based on the six categories; ease of access, perceived usefulness of Google Classroom quality of usage, learning effectiveness, assessment and feedback, communication and interaction, and the user's satisfaction. The researcher made an interpretation on the data collected and analyzed based on these categories.

\section{RESULTS AND DISCUSSION \\ 3.1 The Way of Using Google Classroom as Online Learning Platform}

Based on the results of this research it is found that all of teachers provide a tutorial of using Google classroom before starting online learning process, share learning materials and assignments on Google Classroom and also give instruction for the students to do the assignment on Google Classroom. Four teachers give instruction for the students to log into their respective accounts and set assignment deadline on Google Classroom. In using Google Classroom there are three teachers add students who have not joined Google Classroom. Two from five teachers provide learning announcement on Google Classroom and three teachers provide learning announcement by using WhatsApp Group. One teacher provides learning announcement on the Google Classroom platform and the other tracher provided learning announcement via WhatsApp Group because Google Classroom doesn't provide an announcement features.

This result indicates that the teachers have positive perception on the Google Classroom. The teachers use Google Classroom in the right way. The teachers also creatively use other application like WhatsApp when they face limitation on the use og Google Classroom in term of announcement feature. The teachers must consider that the clear communication among the teachers and students should be implemented in learning process. Thomson (2010) impresses that the communication is one of the most essential and suitable element in online learning [12]. This positive perception of teacher is something that is expected in the online learning purposes. 


\subsection{Teachers' Perception on Using Google Classroom as Online Learning Platform}

In this research, the researcher analyzed the data about teachers' perception with the indicators; Ease of Access, Perceived of Usefulness, Quality of Usage, Learning Effectiveness, Assessment and Feedback, Communication and Interaction, and Teachers' Satisfaction on using Google Classroom.

Based on the result it is found that the teachers' perception on the use of Google Classroom is categorized into positive with rate respondent $71 \%$. The highest response rate $(77 \%)$ is on the indicator learning effectiveness while the lowest response rate (67\%) is on indicator perceived usefulness. Despite of this result, the response rate for the whole teachers' perception is categorized as positive perception.

The results are largely supported by many studies. It can be understood that Google Classroom users can feel that all the facilities and functions provided by Google Classroom are easy to use and easy to access, so that they can easily complete classroom tasks. This statement is stated by Davis[13] and Yulianto [14], which expresses views on the ease of use and perceived usefulnees of Google Classroom.

This result indicates that the teachers consider the use of Google Classroom fulfill all of the teacher and students needs in online learning facilitation; Ease of Access, Perceived of Usefulness, Quality of Usage, Learning Effectiveness, Assessment and Feedback, Communication and Interaction, and Teachers' Satisfaction. This might be the teacher readiness and adaptation ability in any changes of situation that might be happen in learning processes. Martin (2019) states that the readiness of the teacher is the most essential factor to prepare in an online learning [15]. Therefore, the teacher perceptions on the use of Google Classroom are positive in line with their readiness to online learning.

\section{CONCLUSIONS}

Teacher perception on using Google Classroom is essential in conducting an online learning that is different from normal type of learning. The result of this result finds that the teachers have positive perceptions on using Google Classroom and its use in online learning. In conclusion, the teachers use Google Classroom in a right way and have positive perception on its use. The teachers consider that the Google Classroom fulfills the Ease of Access, Perceived of Usefulness, Quality of Usage, Learning Effectiveness, Assessment and Feedback, Communication and Interaction, and Teachers' Satisfaction in online learning.

\section{ACKNOWLEDGMENTS}

I would like to dedicate my deepest gratitude to Prof. Dr. Jufrizal, M. Hum and Dr. Zul Amri, M.Ed who have provided time, help, willingness, and great advice for this journal.

\section{REFERENCES}

[1] Anderson, T. (2008). The Theory and Practice of Online Learning. Second Edition. AU Press Canada. Athbasca University.

[2] Carliner, S. 1999. An overview of online learning $\left(1^{\text {st }}\right.$ ed.). Armherst, MA: Human Resource Development Press

[3] Osubor, V. I., \& Chiemeke, S. C. (2015). ELearning Functional Model : A Technology-Based Teaching Method For Providing Access To Sustainable Quality Education ., 8(2).

[4] Khan,B. 1997. Web-based training. Englewood Cliffs, NJ: Educational Technology Publications.

[5] Dhull, Indira, \& Sakshi. (2017). Online Learning. International Education \& Research Journal, Vol $3(8), \mathrm{p} 1$.

[6] Beal, V. (2017). Google Classroom. Webopedia. http://www.webopedia.com/TERM/G/googleclassroom.html

[7] Janzen, M. (2014). Hot Team: Google Classroom. https//:tlt.psu.edu/2014/12/4hot-team-googleclassroom.html

[8] Iftakhar, S. (2016).Google Classroom; What Works and How? Juornal of Education and Social Science. Vol 3 (7).

[9] Nagele, N. (2017). Udemy. Retrieved from Udemy.com:https://www.udemy.com/googleclassr oom/

[10] Hakim, A. B. (2016). Efektifitas Penggunaan ELearning Moodle, Google Classroom dan Edmodo. I-STATEMENT, 2(1). 1-6

[11] Pappas, C. (2015). Google Classroom Review: Pros and Cons of Using Google Classroom in $e$ Learning. E learning Industry.

[12] Thomson, L. D. (2010). Beyond the classroom walls: Teachers' and students' perspectives on how online learning can meet the needs of gifted students. Journal of Advanced Academics, 21(4),662-712

[13] F. D. Davis, Perceived usefulness, perceived ease of use, and user acceptance of information technology, MIS quarterly, pp. 319-340, 1989.

[14] S. E. Yulianto, Pengaruh Persepsi Kemudahan dan Persepsi Kemanfaatan terhadap Pemanfaatan elearning dengan Model TAM di SMK Muhammadiyah 3 Yogyakarta, Jurnal Sistem Informasi, vol. 1, 2011.

[15] Martin, F., Budhrani, K., \& Wang, C. (2019). Examining faculty perception of their readiness to Teach Online. Online Learning Journal, 23(3), 97-119. 